\title{
Communicating climate change: Improving the effectiveness of public campaigns
}

\section{Comunicación sobre el cambio climático: Mejorando la eficacia de campañas públicas}

\author{
María del Carmen Hidalgo Villodres, Fernando Casado Castro and Patricia García-Leiva
}

Departamento de Psicología Social, Antropología Social, Trabajo Social y Servicios Sociales. Universidad de Málaga, España

Disponible online 31 de agosto de 2014

\begin{abstract}
Research on climate change highlights the need to develop more effective campaigns to increase citizens' awareness of this issue, increase their willingness to accept the measures necessary to halt this phenomenon and change their behaviour. This paper describes a study which analyzed the effectiveness of an advertising message that combined informative and motivational variables on pro-environmental attitudes and intended behaviour. The study sample consisted of 180 university students, divided into two equivalent groups. The results supported the initial hypothesis, the participants in the group that received specific behaviour guidelines (to increase perceived control) together with information on economic savings (motivational variable) displayed more changes in self-efficacy, pro-environmental attitudes and intention of behaviour than the group that did not receive this information.
\end{abstract}

Key words: environmental communication, climate change, pro-environmental attitude, behavioral intention.

La investigación sobre cambio climático pone de manifiesto la necesidad de desarrollar campañas más efectivas para aumentar la concienciación de los ciudadanos y su disposición a aceptar las medidas necesarias para poner fin a este fenómeno y cambiar sus comportamientos. Este artículo describe un estudio que analiza la eficacia de un mensaje publicitario que combina variables informativas y motivacionales en relación a la actitud pro-ambiental y la intención de conducta. La muestra consistió en 180 estudiantes universitarios, divididos en dos grupos equivalentes. Los resultados apoyan la hipótesis inicial, los participantes del grupo que reciben pautas específicas de comportamiento (para aumentar la percepción de control) junto con información sobre ahorro económico (variable motivacional), muestran puntuaciones más altas en autoeficacia, actitud proambiental e intención de conducta que el grupo que no las recibe.

Palabras clave: comunicación ambiental, cambio climático, actitud proambiental, intención de conducta.

Correspondence concerning this article should be addressed to: $\mathrm{M}^{\mathrm{a}}$ Carmen Hidalgo Villodres. Facultad de Psicología, Campus de Teatinos s/n, Universidad de Málaga, 29071 Málaga-España. Tel.: 0034952132435 FAX: 00349521311 00. E-mail: mchidalgo@uma.es. Authors’ E-mails: Fernando Casado Castro: fcasado@uma.es; Patricia García-Leiva: patricia@uma.es 
It is widely agreed that winning the battle against climate change requires major changes in our lifestyle. The promotion of pro-environmental behavior through different intervention strategies and techniques has a long tradition in social and environmental psychology. Since the 1970s, intervention programs have been developed to promote household energy saving, recycling, use of public transport, etc. The most common intervention strategies used to encourage pro-environmental behavior are, according to Geller et al. (1990): information, personal commitment, goal setting and modeling (antecedent strategies), as well as feedback and the use of incentives or penalties (consequent strategies). De Young (1993) proposes another interesting classification: information techniques, positive motivational techniques and coercive techniques. Pol, Vidal and Romeo (2001) also carried out an exhaustive review of the strategies used in both social and environmental marketing, classifying them into the so-called four-spheres model, namely rationality, emotiveness, functionality or comfort and influence or social control.

Abrahamse, Steg, Vlek and Rothengatter (2005) conducted a detailed review focusing on the effectiveness of each of these forms of intervention, reporting different levels of success in different studies. According to the results reported by different authors, the ideal intervention is a combination of strategies, such as information and feedback (e.g. the Ecoteam Program, Staats, Harland \& Wilke, 2004), information and commitment (Katzev \& Johnson, 1983, 1984) or goal setting and feedback (Van Houwelingen \& Van Raaij, 1989). Other earlier reviews that reached similar conclusions include the study by Porter, Leeming and Dwyer (1995) on recycling behavior or the review conducted by Dwyer, Leeming, Coburn, Porter and Jackson (1993) on behavioral interventions to preserve the environment. However, the scope of these programs is limited due to the financial and human resources necessary to carry out these programs on a large scale.

\section{The Mass media as a tool for promoting pro-environmental behavior}

Communication campaigns reach large audiences but their effectiveness is often questioned. More studies are needed to better understand how develop more effective campaigns. Considering the social importance of this topic and the enormous financial resources required to develop media campaigns targeted at the general population, more applied research in this field can also help optimizing the use of those resources. Many authors have emphasized the need to develop more effective campaigns to raise citizens' awareness, to increase their willingness to accept the measures necessary to mitigate climate change and to ultimately change their behavior patterns (Abrahamse, Steg, Vlek \& Rothengatter, 2005; Mors, Weening, Ellemers \& Daamen, 2010; Steg \& Vlek, 2009; Whitmarsh, O'Neill \& Lorenzoni, 2011). In this line, Bator and Cialdini (2000), two of the most important researchers on the subject of social influence, claimed that "although there is a great deal of persuasion research that addresses attitude change and corresponding behavior change, public service announcements are typically designed without taking advantage of this information" (p. 528).

Moreover, Steg and Vlek (2009) claimed that studies evaluating the effectiveness of advertising messages should follow experimental research designs that reveal the effectiveness of individual and combined interventions with one or more treatment groups and one control group, although this is rarely the case in practice. Some examples in this field include the research by Van Zomeren, Spears and Leach (2010), who analyzed experimentally the power of fear and group efficacy beliefs to increase environmental action in order to combat climate crisis. Mors, Weening, Ellemers and Daamen (2010) found in an experimental study that participants perceived factual information from collaborating stakeholders to be of higher quality than when such information was provided by individual stakeholders. Hart (2011) also performed an experimental study and found that participants exposed to a thematic framework (general trends and information about an issue) were more supportive of policies that addressed climate change than participants exposed to an episodic framework (a case study of the topic). However, it is not known whether mentioning the causes of environmental problems is more or less effective than highlighting the most immediate consequences of such problems. Or whether referring to the future consequences has more or less effect than alluding to the more immediate consequences. The same can be said of the inclusion or exclusion of coping strategies.

Numerous authors conclude that information campaigns tend to result in greater knowledge but hardly induce any behavioral changes (Abrahamse et al., 2005; Lehman \& Geller, 2004; Schultz, Oskamps \& Mainieri, 1995; Steg \& Vlek, 2009). The limited data available show this to be the case. For instance, Staats, Wit and Midden (1996) evaluated the effects of a campaign conducted in Germany on the greenhouse effect. They concluded that the level of knowledge of the problem increased, but not the level of awareness. Intended pro-environmental behavior increased, but only among people who already behaved in a pro-environmental manner before the campaign. The lack of a comprehensive set of studies that analyze and systematically compare the effectiveness of information contained in environmental communication campaigns has resulted in a high degree of uncertainty about the effectiveness of these campaigns.

\section{Considering a mass persuasion strategy}

In recent years, however, researchers have increasingly used communication theories to address how to best communicate with the public about climate change (Hart, 2011; Maibach, Roser-Renouf \& Leiserowitz, 2008; Moser \& Dilling, 2007; Nisbet \& Kotcher, 2009). For example, it is widely 
known in other areas of social psychology that the use of fear in advertising is not effective unless it is accompanied by coping guidelines or strategies. This has also been proven in the field of environmental psychology by O'Neill \& NicholsonCole (2009). Still, many real campaigns continue to be based mainly on this emotion. Likewise, numerous researchers have highlighted the importance of providing specific guidelines to increase perceived behavioral control. Bamberg and Moser (2007) carried out a meta-analysis of research on responsible environmental behavior with a total of 57 samples. They postulated a model to integrate the two main theories in the field: The Norm-Activation Model (Schwartz, 1977) and the Theory of Planned Action (Azjen, 1991). They found that the main predictor of the intention to perform pro-environmental behavior was perceived behavioral control $(\beta=.31)$, followed by attitude $(\beta$ $=.29)$ and moral norm $(\beta=.29)$. Similar results were reported by Armitage and Conner (2001). In the same line, Bator and Cialdini (2000) highlighted the need to design publicity campaigns with very specific messages showing how to resolve specific problems (Pratkanis \& Greenwald, 1993).

Other studies have reported that the limited effectiveness of the many programs promoting public engagement to mitigate climate change is related to the fact that they do not address the personal motivations of the audience. The reasons that motivate people to adopt certain types of environmental behavior vary enormously. In addition to purely environmental reasons, other motivations such as social, economic, political or health motivations are often ignored (Hart, 2011; Hoppner \& Whitmarsh, 2011; Whitmarsh, 2009). For example, Whitmarsh (2009) found that the main motivation for adopting effective behavior against climate change, such as turning off lights or using energy-saving light bulbs, was not pro-environmental but economical. Examples of behaviors with a pro-environmental goal include recycling, which has a lower impact on climate change, giving rise, in the words of the aforementioned author, to "an asymmetry of intentions and of impacts of behavioral responses to climate change". However, many of these programs focus on relevant environmental reasons. In this respect, many authors have stressed the need to motivate audiences in order to achieve social change and have concluded that this motivation should be directed at "what does matter to your audience, not what should matter to them" (Reardon, 1991, p. 226).

\section{The present study}

Taking into account the results of previous studies, an applied study integrating some of their recommendations was carried out. According to Bamberg and Moser (2007), to increase people's perceived behavioral control, their ability to perform the behavior must be strengthened. For this purpose, it was designed a message to improve this ability by providing specific information on what they could do to combat climate change. Additionally, based on the results of motivational studies (Chess \& Johnson, 2007; Whitmarsh, 2009), the adoption of effective behaviors against climate change was reinforced through an additional reason to adopt such behavior: the economical benefits.

The effectiveness of an advertising message combining informative and motivational variables was analyzed. Specifically, it was examined the effect of an audiovisual advertisement presenting information on climate change and specific guidelines on actions to reduce $\mathrm{CO}_{2}$ emissions (the main cause of climate change) together with the personal economic benefit of such actions. By providing this combined information it was intended to increase the perceived control of behavior of the spectators (increasing their knowledge of both the problem and the possible solutions) and their motivation to carry out such actions.

With this aim, it was examined the effect of a message that combined an informative strategy (specific behavioral guidelines against climate change) and a motivational strategy (the economic savings of this behavior) on knowledge, attitude and pro-environmental behavioral intention. It was postulated that participants receiving specific guidelines and information on how to make savings would develop more favorable attitudes and a greater intention to behave in this way than those who only received general information about the causes of climate change. On this basis, two main hypotheses were proposed: a) The group receiving specific behavioral guidelines (high level of perceived control) together with information on how to make economic savings (motivation) would display greater self-efficacy and greater concern for climate change than the group not receiving the aforementioned guidelines and information; b) The group receiving specific behavioral guidelines and information on economic savings would present greater intended pro-environmental behavior in the future than the group not receiving such information.

\section{Method}

The proposed study was first performed with a pilot group of 16 students enrolled on the Psychology Degree at the University of Malaga. The students watched the videos and completed the questionnaires. Based on their observations, the information in the advertisements was adapted (text was reduced, font size increased, sequence change speed reduced and the video soundtrack changed) and data collection time was estimated. Once the necessary changes had been made, the study described below was performed.

\section{Participants}

One hundred and eighty students participated in this study (control group, $\mathrm{CG}=91$ and experimental group, $\mathrm{EG}=89$ ) from two different degrees at the University of Malaga in Spain: Social Work (36.2\%) and Labor Relations (63.8\%). There were no significant differences in the socio-demographic variables between the control group (CG) and the experimental group (EG). Regarding sex, the percentage of women in the EG were 
$89.80 \%$ while in the $\mathrm{CG}$ the percentage was $81.3 \%$, the average age was $23.93(S D=6.4)$ in the EG and $22.49(S D=5.5)$ in the $\mathrm{CG}$, the $74.2 \%$ were living with parents in the EG and the $71.2 \%$ were in the same situation in the CG.

Likewise, no significant differences were found in political ideology $(F(1,171)=.37, p<.847)$, degree of involvement in activities of different socio-political groups $(F(1,179)=.69, p<$ $.793)$, recent participation of environmental actions $(F(1,180)$ $=.60, p<.806)$, and involvement in the activities of environmental groups $\left(X^{2}(4,178)=.159 p<.997\right)$.

\section{Instruments}

Data were gathered using a questionnaire with questions on the following: sex, age, person/s with whom the participant lived (family, friends, partner...), political ideology, degree of involvement in the activities of different organizations, environmental actions performed recently, involvement in the activities of environmental groups, general knowledge about climate change, perceived self-efficacy to mitigate climate change, specific attitude towards climate change and intended future behavior to reduce $\mathrm{CO}_{2}$ emissions.

Firstly, socio-demographic variables were collected: sex, age, and persons with whom the participant lived. This set of variables guaranteed the equivalence between the experimental group and the control group and were selected based on the results of previous studies (Berenguer, 2000; Fraj and Martínez, 2002). The political ideology of individuals was measured on a scale of 1 to 9: 1 ("extreme right") and 9 ("extreme left"). Involvement or membership in socio-political organization (political party, neighborhood association, sports association, leisure or cultural association, educational association, trade union, other group) was measured as: 1 ("I am not a member"), 2 ("I am a member but do not participate at all), 3 (I only attend social events), 4 ("I help organize events), 5 ("I participate in discussions and decisions of the organization"). This classification was treated as a continuous variable in which a lower score indicated that the person had a less participative profile and slightly low reliability (.50) but was maintained because it was only required to ensure sample equivalence. This scale was adapted from another one developed by the Institute of Social Studies of Andalusia (IESA) to identify the participatory profile of citizens involved in participatory budgeting processes (Ganuza, 2007). Recent environmental actions were evaluated on a 7 -item scale measuring different pro-environmental actions, with possible responses ranging from 1 ("never") to 5 (always). This scale had a reliability of .70 and was adapted for the ecological context from the scale developed by Speer and Peterson (2000) for the behavioral empowerment dimension. The degree of involvement in the activities of an environmental organization was identified in the same way as the participatory profile, but in this case, given the nature of the current study, the response format used was based on categories, i.e. separately item by item, the response format being categorical-ordinal.
The remaining instruments had to be constructed by the authors because there were not scales of this type specifically developed in the field of climate change. They were designed using similar scales, adapting the items to the aims of the study. Knowledge about climate change was measured using a 5-item scale with a Likert-type response format ranging from 1 ("strongly disagree") to 7 ("strongly agree"), with a reliability of .60. The items were: "Acid rain is one of the causes of climate change", "Greenhouse gas emissions are the main cause of climate change", "Climate change is due to natural causes and not to human activity", "The increase in atmospheric temperature is due to the growing and continual use of fossil fuels (coal, petrol, etc.)" and "Global warming is a consequence of the hole in the ozone layer". These items were related to the information provided in the experimental advertisements.

Self-efficacy measured the perception of personal/individual capacity to mitigate climate change. It consisted of 2 inverse items with a response format ranging from 1 ("strongly disagree") to 7 ("strongly agree"). This scale was also developed by the authors of this study and had a moderate alpha value (.50). The two items on this scale were: "I cannot do anything to combat climate change" and "I think that citizens who behave like us mitigate climate change on our planet".

Specific attitude towards climate change was evaluated on a 6-item scale with answers ranging from 1 ("strongly disagree") to 7 ("strongly agree"). This scale, also developed by the authors, presented a reliability of .70 . The scale comprised the following items: "I am not interested in the phenomenon of climate change", "Too much emphasis has been placed on the phenomenon of climate change", "Countries that breach the Kyoto Protocol should be penalized", "Many affirmations about climate change are exaggerated", "I am worried about the situation that climate change causes or will cause in the future" and "I believe that the problem of climate change is not as serious as people say".

Finally, intended future behavior measured the extent to which the participants would change their behavior in relation to the elements which appeared on the publicity spot, such as purchasing Class-A electrical appliances or turning off computers and printers when not in use. This scale was constructed from the previous scale, indicating in all cases that it referred to the future. The alpha value was $\alpha=.70$. The items on the scale were: "Purchase more efficient Class-A electrical appliances", "Turn off the computer and printer when I finish work", "Put on stand-by all electrical appliances with this function", "Disconnect electrical appliances and chargers from the mains when I am not using them", "Use low-consumption light bulbs", "Avoid braking unnecessarily", "Avoid accelerating unnecessarily", "Walk when I have to travel short distances" and "When I have to take a route that I can do by bicycle, I will go by bicycle". Each of these items referred to each specific guideline shown in the advertisement. 


\section{Procedure}

An intergroup experimental design was developed with one independent variable with two levels: one with and one without perceived behavior control and economic motivation. The following dependent variables were used: general knowledge about climate change, specific attitude toward climate change, self-efficacy and future behavioral intention. The following variables were controlled to ensure the comparability of the sample and to determine the effect of the independent variable: socio-demographic variables (level of education, sex, age, cohabitation), political ideology, involvement in the activities of various groups, recent environmental actions and involvement in the activities of environmental groups. The persuasion factors were also controlled by ensuring a single source to prevent this from having an influence and by presenting the same structure in the message (the superimposed text appeared in the same sequence and in the same order in both conditions). Therefore, the content of the message (strictly argumental) was the manipulated variable. This design aimed to activate the central processing route (Cialdini, Petty \& Cacioppo, 1981; Petty \& Cacioppo, 1986).

The levels of the independent variable were obtained by developing two TV advertisements of the same duration ( 90 seconds). In the first video, the audiovisual content on the negative effects of $\mathrm{CO}_{2}$ emissions was accompanied by superimposed text on the screen indicating specific behavioral recommendations for reducing $\mathrm{CO}_{2}$ emissions with the corresponding cost savings. The second video, with the same audiovisual content, provided general information on the negative effects of $\mathrm{CO}_{2}$, but without the text superimposed on the screen presenting specific recommendations on actions and economic savings. This text was replaced for another text containing general and vague information on the amount of $\mathrm{CO}_{2}$ emitted by different sources.

In summary, both advertisements were identical in terms of images and sound except for the superimposed text message. In condition 1 (behavioral control and financial reward), the participants, after listening to a brief voiceover on the relationship between $\mathrm{CO}_{2}$ emissions and climate change, read the following text: "What can we do? You can act. Buy the most energyefficient, Class A label products, you can save up to 400 euros per year and you will stop emitting a large amount of $\mathrm{CO}_{2}$ " (Figure 1 depicts a frame of the advertisement shown to participants in condition 1). Participants in condition 2 were presented with the following text: "Electrical appliances consume a huge amount of energy and emit large amounts of $\mathrm{CO}_{2}$ " (Figure 2 depicts a frame of the advertisement shown to participants in condition 2). The same approach was adopted with computers and mobile phones, light bulbs, braking and accelerating in a vehicle, as well as with the use of vehicles to travel short distances compared with cycling or walking. The aspects and behaviors selected for this study are some of those most directly related to $\mathrm{CO}_{2}$ emissions, in accordance with the recommendations of Geller (2002), who stated that behavioral change is more effective when the behaviors to be changed are carefully selected, as well as numerous authors who describe behaviors that significantly affect environmental quality.

\section{Figure 1}

Condition 1 advertisement: Behavioral control and financial reward

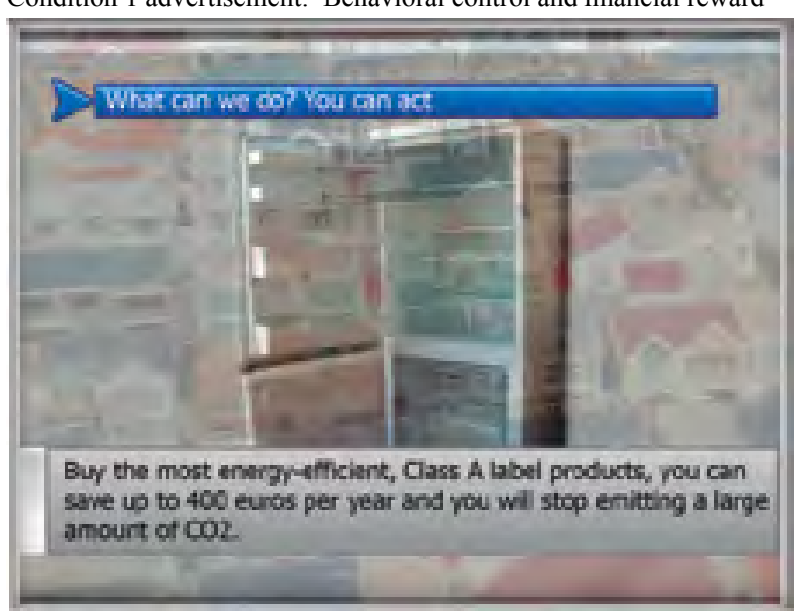

Figure 2

Condition 2 advertisement: General information on the negative effects of $\mathrm{CO} 2$

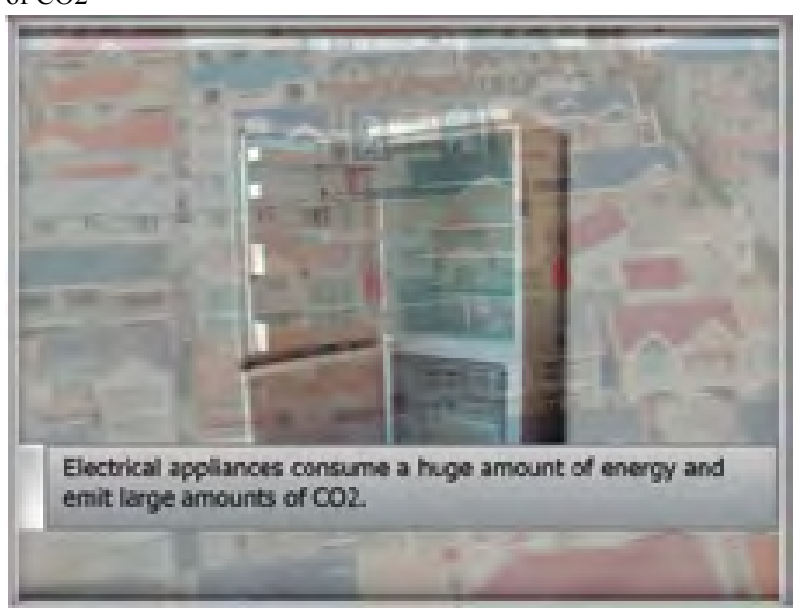

Both conditions were viewed separately in the classroom and during class hours, participation was voluntary and anonymous. After exposure to the corresponding condition, the students were given the questionnaire described above. All the elements that appeared in the videos (vehicles, computers, light-bulbs, etc.) were the same as the ones they were asked about in the questionnaires on intended future behavior. The content of the questionnaire was not balanced and appeared in exactly the same order for both groups.

\section{Results}

The overall analysis of the variables used in the study showed that specific attitude towards climate change was positively correlated with level of knowledge $(r=.42, p<.01)$ and 
Table 1

Comparison of dependent variables in both conditions. ANOVA.

\begin{tabular}{|c|c|c|c|c|c|}
\hline $\begin{array}{c}\text { Dependent } \\
\text { Variables }\end{array}$ & $\begin{array}{l}\text { Experimental } \\
\text { condition }\end{array}$ & $\begin{array}{c}\text { Control } \\
\text { condition }\end{array}$ & $d f \mathrm{gl}$ & $F$ & Significance \\
\hline Specific attitude towards CC & $\begin{array}{c}5.8 \\
(S D=1)\end{array}$ & $\begin{array}{c}5.4 \\
(S D=1.0)\end{array}$ & 1 & 5.453 & .021 \\
\hline Self-efficacy & $\begin{array}{c}6.1 \\
(S D=1.2)\end{array}$ & $\begin{array}{c}5.6 \\
(S D=1.5)\end{array}$ & 1 & 5.225 & .023 \\
\hline Knowledge & $\begin{array}{c}5.6 \\
(S D=.9)\end{array}$ & $\begin{array}{c}5.6 \\
(S D=1.0)\end{array}$ & 1 & 0.161 & .688 \\
\hline
\end{tabular}

self-efficacy $(r=.32, p<.01)$. Furthermore, these two variables (knowledge and self-efficacy) were correlated with each other $(r=.22, p<.01)$. Therefore, there was a relationship between degree of knowledge, attitude and self-efficacy of people towards climate change.

The analysis of variance supported the two hypotheses proposed (see Table 1): the students who received specific information about how to reduce $\mathrm{CO}_{2}$ emissions in their daily lives and about the associated economic benefits displayed a greater attitude towards climate change $(F(1,178)=5.453, p=.021)$ and were more inclined to try to reduce $\mathrm{CO}_{2}$ emissions in the future $(F(1,178)=8.390, p=.004)$ than those who did not receive such information. Similarly, the level of self-efficacy was higher in the experimental condition $(F(1,180)=5.225$, $p=.023)$. Therefore, the combination of specific information with incentives seemed to effectively promote pro-environmental attitude and behavioral intention. Similarly, providing specific information on behaviors to reduce $\mathrm{CO}_{2}$ emissions seemed a good strategy for encouraging self-efficacy and thus increasing perceived control, although this variable must be studied independently and a scale providing higher reliability needs to be developed.

Table 1 also shows that the level of general knowledge about climate change was high in both samples and no significant differences were observed between them $(\mathrm{F}(1,178)=.161$, $\mathrm{p}=.688)$. This result was expected in view of the characteristics of the independent variable. It was provided the same general information to both groups, introducing the modification in behavioral strategies and the savings that would entail. This dependent variable measured knowledge about the causes of climate change, this information was given to both groups on an equal basis.

Pearson's correlation analysis revealed a positive relationship between attitude and intended behavior for the experimental condition, $(r=.237, p=.025)$; hence, the greater the attitude towards climate change, the greater the intention to adopt behaviors to reduce $\mathrm{CO}_{2}$ emissions. This relationship was not observed in the control condition $(r=.133, p=.208)$. This finding reinforces the need to provide specific information and reasons for activating the relationship between attitude and intended behavior. Providing general information about climate change does not seem to make people more aware of the problem, nor does it increase their motivation to act.

\section{Discussion}

The results presented in this study strengthen the theory proposed by Bamberg and Moser (2007) in their meta-analysis: perceived control (shown in this research through specific action strategies) seems to increase future pro-environmental behavioral intention. According to the terminology used in the four-sphere model (Pol, Vidal and Romeo, 2001), the combination of the rationality and the functionality spheres exhibited the capacity to influence future behavior.

The results presented here suggest that a message providing specific information to resolve a problem together with a motivation (in this case economic, since previous studies have identified this as the motivational variable with most weight in pro-environmental behavior) effectively triggers a personal intended behavior. The combination of both variables (perceived control and economic motivation) shows how the design of publicity campaigns aimed at reducing $\mathrm{CO}_{2}$ emissions can be improved to be more effective.

The results obtained in this study, supported by previous research, indicates that investments in purely informative publicity campaigns increase knowledge but do not necessarily have an impact on behavioral intention. This finding is extremely relevant from the standpoint of the application of environmental policies since if climate change is to be mitigated, citizens must be made aware of the need to readjust their daily habits. However, this requires coordination and collaboration among all stakeholders - Government, NGOs, businesses (Regnier \& Custied, 2011), citizens and researchers - in order to increase the effectiveness of launched initiatives.

The results of this study make a necessary contribution to such collaboration and support a specific approach: information with specific behavioral patterns + economic motivation. Consequently, future advertising campaigns should take into account these key elements in order to be more effective.

The present study has a number of limitations. First, the independent variable should be separated, eliminating the combination of behavioral patterns and economic motivation in order to identify the weight of each element. Second, it would also be interesting to examine the effect of such campaigns on actual behavior and not only on planned behavior as well as determine whether such behavior is maintained in time through a longitudinal design. Third, it would also be useful to use another equivalent control group to estimate the influ- 
ence on the level of general knowledge with respect to climate change and to identify which messages increase knowledge most. Fourth, the participants' profiles also hindered the generalization of the results, so these results must be considered with caution and research must be conducted with representative samples. Finally, it would be advisable to control the social desirability that these types of self-informed responses normally entail. In any case, despite the highlighted limitations, the findings reported here are extremely valuable since they can help designing campaigns to increase awareness and promote pro-environmental knowledge and behavioral intention.

Future research will address these weaknesses; also, in order to enhance the persuasive power of campaigns, persuasion strategies should take into account not only the characteristics of the message, but also the characteristics of the source, the emotiveness and the social control spheres.

\section{References}

1. Abrahamse, W., Steg, L., Vlek, C. \& Rothengatter, T. (2005). A review of intervention studies aimed at household energy conservation. Journal of Environmental Psychology, 25, 273-291. http://dx.doi.org/10.1016/j.jenvp.2005.08.002

2. Ajzen, I. \& Fishbein, M. (1980). Understanding Attitudes and Predicting Social Behavior. Englewood Cliffs, NJ: Prentice Hall.

3. Armitage, C. J. \& Conner, M. (1999). Predictive validity of the theory of planned behavior: The role of questionnaire format and social desirability. Journal of Community and Applied Social Psychology, 9, 261-272. http://dx.doi. org/10.1002/(SICI)1099-1298(199907/08)9:4<261::AIDCASP503>3.0.CO;2-5

4. Azjen, I. (1991). The theory of planned behavior. Organizational Behavior and Human Decision Processes, 50, 179211. http://dx.doi.org/10.1016/0749-5978(91)90020-T

5. Bamberg, S. \& Moser, G. (2007). Twenty years alter Hines, Hungerford and Tomera: A new meta-analysis of psychosocial determinants of pro-environmental behavior. Journal of Environmental Psychology, 27, 14-25. http://dx.doi. org/10.1016/j.jenvp.2006.12.002

6. Bator, R. J. \& Cialdini, R. B. (2000). The application of persuasion theory to the development of effective proenvironmental public service announcements. Journal of Social Issues, 56, 527-41. http://dx.doi.org/10.1111/00224537.00182

7. Berenguer, J. (2000). Actitudes y creencias ambientales. Una aplicación psicosocial del comportamiento ecológico. Cuenca: Ediciones de la Universidad de Castilla La Mancha.

8. Chess, C. \& Johnson, B.B. (2007). Information is not enough. In S. Moser y L. Dilling (Eds.), Creating a climate for change. Communicating climate change and facilitating social change (pp. 223-233). New York: Cambridge University Press. http://dx.doi.org/10.1017/

\section{CB09780511535871.017}

9. Cialdini, R. B. (1993). Influence: Science and practice (3rd ed.). New York: Harper Collins.

10. Cialdini, R. B., Petty, R. E. \& Cacioppo, J. T. (1981). Attitudes and attitude change. Annual Review of Psychology, 32, 357-404. http://dx.doi.org/10.1146/annurev. ps.32.020181.002041

11. Davidson, S. (2011). Up-scaling social behavior change programmes: The case of Eco Teams. In L. Whitmarsh, S. O'Neill and I. Lorenzoni (Eds.), Engaging the public with climate change. Behavior change and Communication (pp. 180-199). London: Earthscan.

12. De Young, R. (1993). Changing behavior and making it stick. The conceptualization and management of conservation behavior. Environment and Behavior, 25, 485-505. http://dx.doi.org/10.1177/0013916593253003

13. Dwyer, W. O., Leeming, F. C., Coburn, M. K., Porter, B. E. \& Jackson, J. M. (1993). Critical review of behavioral interventions to preserve the environment. Research since 1980. Environment and Behavior, 25, 275-321. http:// dx.doi.org/10.1177/0013916593255001

14. Fraj, E. \& Martínez, E. (2002). Comportamiento del consumidor ecológico. Madrid: ESIC Editorial.

15. Ganuza, E. (2007). Tipología y modelos de presupuestos participativos en España. Córdoba: IESA Working paper series. $N^{\circ} 1307$. IESA-CSIC.

16. Geller, E. S. (2002). The challenge of increasing pro-environmental behavior. In R. G. Bechtel \& A. Churchman (Eds.), Handbook of Environmental Psychology (pp. 525540). New York: Wiley.

17. Geller, E. S., Berry, T. D., Ludwig, T. D., Evans, R. E., Gilmore, M. R., \& Clark, S. W. (1990). A conceptual framework for developing and evaluating behavior change interventions for injury control. Health Education Research: Theory and Practice, 5, 125-137. http://dx.doi. org/10.1093/her/5.2.125

18. Hart, P. S. (2011). One or Many? The Influence of Episodic and Thematic Climate Change Frames on Policy Preferences and Individual Behavior Change. Science Communication 33, 28-51. http://dx.doi.org/10.1177/1075547010366400

19. Hoppner, C. \& Whitmarsh, L. (2011). Public engagement in climate action: Policy and public expectations. In L. Whitmarsh, S. O'Neill and I. Lorenzoni (Eds.), Engaging the public with climate change. Behavior change and Communication (pp. 47-65). London: Earthscan.

20. Katzev, R. D. \& Johnson, T. R. (1983). A social-psychological analysis of residential electricity consumption: The impact of minimal justification techniques. Journal of Economic Psychology, 3, 267-284. http://dx.doi. org/10.1016/0167-4870(83)90006-5

21. Katzev, R. D. \& Johnson, T. R. (1984). Comparing the effects of monetary incentives and foot-in-the-door strategies in promoting residential electricity conservation. Jour- 
nal of Applied Social Psychology, 14, 12-27. http://dx.doi. org/10.1111/j.1559-1816.1984.tb02217.x

22. Lehman, P. K. \& Geller, E. S. (2004). Behavioral analysis and environmental protection: Accomplishments and potential for more. Behavior and Social Issues, 13, 13-32. http://dx.doi.org/10.5210/bsi.v13i1.33

23. Mors, E. M., Weening, M. W. H., Ellemers, N. \& Daamen, D. D. L. (2010). Effective communication about complex environmental issues: Perceived quality of information about carbon dioxide capture and storage (CCS) depends on stakeholder collaboration. Journal of Environmental Psychology, 30, 347-357. http://dx.doi.org/10.1016/j. jenvp.2010.06.001

24. O'Neill, S. \& Nicholson-Cole, S. (2009). "Fear won't do it": Promoting positive engagement with climate change through visual and iconic representations. Science Communication, 30, 355-379. http://dx.doi. org/10.1177/1075547008329201

25. Petty, R.E. \& Cacioppo, J.T. (1986). The Elaboration Likelihood Model of persuasion. In L. Berkowitz (Ed.), Advances in experimental social psychology, vol. 19 (pp. 123-205). New York: Academic Press.

26. Pol, E., Romeo, M. \& Vidal, T. (2001). Supuesto de cambio de actitud y conducta usados en las campañas de publicidad y los programas de promoción ambiental: el modelo de las cuatro esferas. Estudios de psicología, 22, 111-125. http:// dx.doi.org/10.1174/021093901609550

27. Porter, B. E., Leeming, F. C. \& Dwyer, W. O. (1995). Solid waste recovery: A review of behavioral programs to increase recycling. Environment and Behavior, 27, 122152. http://dx.doi.org/10.1177/0013916595272002

28. Pratkanis, A. R. \& Greenwald, A. G. (1993). Consumer involvement, message attention, and the persistence of persuasive impact in a message-dense environment. Psychology \& Marketing, 10, 321-332. http://dx.doi.org/10.1002/ mar.4220100406

29. Reardon, K. E. (1991). Persuasion in Practice. CA: Sage.

30. Regnied, G. \& Custied, S. (2011). The role and effectiveness of governmental communications in engaging the public with climate change. In L. Whitmarsh, S. O'Neill and I. Lorenzoni (Eds.), Engaging the public with climate change. Behavior change and Communication (pp. 200216). London: Earthscan.

31. Schultz, P., Oskamps, S. \& Mainieri, T. (1995). Who recycles and when? A review of personal and situational factors. Journal of Environmental Psychology, 15, 105-121. http:// dx.doi.org/10.1016/0272-4944(95)90019-5
32. Speer, P. \& Peterson, A. (2000). Psychometric properties of an empowerment scale: Testing cognitive, emotional and behavioral domains. Social Work Research, 24, 109-118. http://dx.doi.org/10.1093/swr/24.2.109

33. Staats, H. J., Wit, A. P. \& Midden, C. Y. H. (1996). Communicating the greenhouse effect to the public: Evaluation of a mass media campaign from a social dilemma perspective. Journal of Environmental Management, 45, 189-203. http://dx.doi.org/10.1006/jema.1996.0015

34. Staats, H., Harland, P. \& Wilke, H. A. M. (2004). Effecting durable change. A team approach to improve environmental behavior in the household. Environment and Behavior, 36, 341-367. http://dx.doi.org/10.1177/0013916503260163

35. Steg, L. \& Vlek, C. (2009). Encouraging pro-environmental behavior: An integrative review and research agenda. Journal of Environmental Psychology, 29, 309-317. http:// dx.doi.org/10.1016/j.jenvp.2008.10.004

36. Stern, P. C. (1992). Psychological dimensions of global environmental change. Annual Review of Psychology, 43, 269-302. http://dx.doi.org/10.1146/annurev. ps.43.020192.001413

37. Stern, P. C. y Oskamp, S. (1987). Managing scarce environmental resources. In D. Stokols e I. Altman (Eds.), Handbook of Environmental Psychology, vol. 2 (pp. 1043-1088). Nueva York: John Wiley and Sons.

38. Van Houwelingen, J. H. \& Van Raaij, F. W. (1989). The effect of goal-setting and daily electronic feedback on in-home energy use. Journal of Consumer Research, 16, 98-105. http://dx.doi.org/10.1086/209197

39. Van Zomeren, M., Spears, R. \& Leach, C. (2010). Experimental evidence for a dual pathway model analysis of coping with the climate crisis. Journal of Environmental Psychology, 30, 339-346. http://dx.doi.org/10.1016/j. jenvp.2010.02.006

40. Whitmarsh, L. (2009). Behavioral responses to climate change: Asymmetry of intentions and impacts. Journal of Environmental Psychology, 29, 13-23. http://dx.doi. org/10.1016/j.jenvp.2008.05.003

Received 29 November 2013

Received in revised form 4 March 2014

Accepted 25 March 2014 